\title{
Traditional uses of medicinal plants used by Indigenous communities for veterinary practices at Bajaur Agency, Pakistan
}

\author{
Muhammad Abdul Aziz ${ }^{1 *}$, Amir Hasan Khan², Muhammad Adnan and Habib Ullah³
}

\begin{abstract}
Background: The pastoral lifestyle of Indigenous communities of Bajaur Agency is bringing them close to natural remedies for treating their domestic animals. Several studies have been conducted across the globe describing the importance of traditional knowledge in veterinary care. Therefore, this study was planned with the aim to record knowledge on ethnoveterinary practices from the remote areas and share sit with other communities through published literature.
\end{abstract}

Methods: Data was gathered from community members through semi-structured interviews and analyzed through informant consensus factor (Fic) to evaluate the consent of current ethnoveterinary practices among the local people.

Results: In total, 73 medicinal plants were recorded under the ethnoveterinary practices. Most widely used medicinal plants with maximum use reports (URs) were Visnaga daucoides Gaertn., Foeniculum vulgare Mill., Solanum virginianum L., Withania somnifera (L.) Dunal, Glycyrrhiza glabra L., and Curcuma longa L. New medicinal values were found with confidential level of citations for species including Heracleum candicans and Glycerhiza glabra. Family Apiaceae was the utmost family with high number (7 species) of medicinal plants. Maximum number of medicinal plants (32) was used for gastric problems. High Fic was recorded for dermatological (0.97) followed by reproductive (0.93) and gastrointestinal disorders (0.92). The main route of remedies administration was oral.

Conclusions: Current study revealed that the study area has sufficient knowledge on ethnoveterinary medicinal plants. This knowledge is in the custody of nomadic grazers, herders, and aged community members. Plants with new medicinal uses need to be validated phytochemically and pharmacologically for the development of new alternative drugs for veterinary purposes.

Keywords: Folk knowledge, Indigenous communities, Livestock diseases, Fic, Phytopharmacological studies

\section{Background}

The historical utilization of plants as health remedies both for human and animal is centuries old. It has been recognized that plants have the capacity to combat several types of diseases ethnoveterinary medicines, a term generally used for folk skills, beliefs, knowledge, practices, methods related to animals' health, and cure of various ailments in the rural areas [1]. Ethnoveterinary practices have achieved immense significance for the last decade owing to the discovery of some effective

\footnotetext{
* Correspondence: azizmhsd@gmail.com

'Department of Botany, Kohat University of Science and Technology, Kohat 26000, Pakistan

Full list of author information is available at the end of the article
}

ethnoveterinary products [2]. The utilization of traditional remedies poses a cheaper, easier, and sustainable alternative to synthetic drugs and pharmaceuticals [3]. It has been reported that due to lack of proper animal husbandry practices, about $30-35 \%$ of the losses occur in the animals' breeding sectors especially in developing countries [4], where the rural people are heavily dependent on livestock farming for their livelihood activities [5]. The Indigenous communities living in rural and mountainous territories of developing world consider livestock a vital source for economy, social security, and food and is thought to be a symbol of prestige for a particular family [6]. 
Livestock being as a subsector contributes around 56\% of value addition in the agriculture sector and approximately $11 \%$ towards the gross domestic product (GDP). About 30 million people living in the rural areas of the country are involved with the livestock subsector [7]. Hence, livestock raring plays a significant role in poverty reduction strategies. According to the report of economic survey of Pakistan [8], the national herd of Pakistan includes 53.8 million goats, 29.6 million cattle, 27.3 million buffalos, 26.5 million sheep, and 0.9 million camels. People residing in the remote areas utilize medicinal plants for livestock's health. Particularly, the conventional lifestyle of nomadic and pastoralists makes it difficult for them to reach veterinary extension services due to high costs and less availability of allopathic medicines [9].

In South Asia, several ethnoveterinary studies have been conducted [10-18] including Pakistan [6, 9, 19-26]. However, scarce studies on ethnoveterinary medicines have been reported from the Federally Administrated Tribal Areas (FATA) of the country. The tribal areas mainly comprised of mountainous territories where people use medicinal plants to treat livestock's diseases. Traditional ethnoveterinary knowledge is mainly transmitted orally from one generation to another generation in the form of folk remedies, drawing stories, poems, drawing stories, folk myths, songs, and proverbs. This transmission of Indigenous knowledge through oral way faces critical threats of extinction. Therefore, it is necessary to record, document, and encourage the ethnoveterinary medication and integrate them into the existing animal health care services [5].

Bajaur agency is among one of the Federally Administrated Tribal Areas (FATA) of Pakistan having diversity of medicinal plants being used for the livestock's healthcare services. Due to remote nature and lack of quality education, the area has been little explored for the scientific documentations of traditional knowledge. There is a dire need to explore the folk knowledge about the utilization of herbal remedies for veterinary practices prior to being extinct. Hence, the current study was planned to investigate and document the traditional ethnoveterinary knowledge and practices and release it from the custody of knowledge bearers for sharing it with other communities through publish literature.

\section{Methods}

\section{Study area}

Bajaur (Khar: headquarter) is the smallest agency of the FATA having a total area of $1290 \mathrm{~km}^{2}$. It shares $52 \mathrm{~km}$ border with Afghanistan, which is of great importance to Pakistan and the region. The study area lays at an altitude of $1126 \mathrm{~m}$ above the sea level and geographically exists between $34^{\circ}-30^{\circ}$ and $34^{\circ}-58^{\circ}$ latitudes and $71^{\circ}-11^{\circ}$ and $71^{\circ}-30^{\circ}$ longitudes. The Agency is surrounded to the west by Kunar Valley of Afghanistan being separated by the rugged Hindukush hills and other mountain passes known as Nawa Pass, Ghakhi Pass, and Letai Sar being the notable ones. The agency borders on south with Mohmand agency, on east with Lower Dir District and the Panjkora River, and on north with the watershed between Bajaur Agency and District Dir. Moreover, the agency is situated at the extreme end of the Himalayan Range. The areas dominated by agricultural lands are receiving about $800 \mathrm{~mm}$ of average rain fall per annum. The two main tribes of Bajaur Agency known as Tarkani and Utman Khel are mainly populated into seven Tehsils including Barang, Nawagai, Khar, Mamund, Salarzai, Utman Khel, and Chamarkand. By profession, mostly, the people are farmers, teacher, drivers, and doing small scale businesses and jobs inside/outside the country. Almost every household has a herd of domestic animals for socioeconomic gains. There are only three degree-level colleges and five higher secondary schools. Moreover, there are only two government hospitals in the study area, while most people are deprived of modern health facilities, which justify their reliance on local herbalists (Hakims). The study area consists of one veterinary hospital and 20 small dispensaries to treat the domestic cattle. However, the local people still rely on traditional recipes due to larger distances from the aforementioned health centers. The dominant vegetation in the area is comprised of Ailanthus altissimo, Eucalyptus camaldulensis, Ficus carica, Melia azedarach, Morus indica, Morus nigra, Olea ferruginea, Pinus roxburghii, Quercus baloot, and Rumex hastatus.

\section{Ethnomedicinal data collection and ethnographic composition}

In the month of April, respondents were targeted based on their strong reputation in the field of ethnomedicinal knowledge while field survey was conducted from May to August 2016. Field visits were carried out prior to medicinal data collection in order to acknowledge the cooperation of the Indigenous communities. Mr. Amir Hasan Khan, the local occupant of the area, visited different sites with his volunteer team including a taxonomist and a pharmacist. He arranged several meetings with the local representatives known as Maliks, to whom objectives of the study were presented.

A semistructured questionnaire was developed to gather knowledge on ethnoveterinary plants by following the method adopted by Martin [27]. Mostly, the folk knowledge was gathered from nomads, farmers, and aged community members. The interviews were conducted at various places and in the local language called "Pashto." Each informant was acknowledged by presenting the main theme of the study to them in order to gain their consent and trust, which allowed the informants to talk more freely and openly. The recorded information was once again redisplayed to the informants to avoid errors and falsification. 
Data was collected from different sites known as Pashat, Tali, Inayat Kali, Ghar Shamozai, Loe Sum, Barang, Mandal, Khar, Mamund, and Salarzai. Accordingly, the sites were categorized into foot hill villages and mountainous villages (Fig. 1). A total of 80 key respondents were selected belonging to different age groups, i.e., 68 males and 12 females (Table 1). The selection of respondent was based on their high reputation with respect to traditional knowledge on ethnoveterinary plants. Continuous relationships were maintained with the Indigenous communities throughout the course of survey for the strong validation of traditional knowledge.

Preservation and taxonomical verifications of plant species Surveyed ethnoveterinary medicinal plants were collected and identified by taxonomist at the Department of Botany, Shaheed Benazir Bhuto University Sheringal, District Dir (Upper), Khyber Pakhtunkhwa, Pakistan. Species botanical names and their family names were corrected and verified through the website www.kew.org/mpns. After collection, plants were pressed and dried under the shade, were poisoned $\left(1 \% \mathrm{HgCl}_{2}\right.$ solution), and were mounted properly on the herbarium sheets for future reference. Each herbarium sheet was labeled with a voucher number and submitted to the aforementioned department [28, 29].

\section{Data analysis}

For each of the specie, use reports (URs) (citations) were counted. UR may be defined as the utilization of part of a plant species for a particular disease mentioned by an informant. To determine the informant consensus factor (Fic), the reported species were arranged in various groups according to the ailment treated [11]. Ten ailment categories were prepared from the data. To calculate the Fic, we used the formula, i.e., Fic $=\mathrm{Nur}-\mathrm{Nt} /$ Nur -1 . Here, Nur indicates the number of citations in each use category and $\mathrm{Nt}$ represents the number of species cited.

\section{Results and discussion}

Prospects and challenges to traditional ethnoveterinary knowledge

Indigenous communities play significant role in reporting traditional uses of medicinal flora. Indigenous knowledge can be used as a tool to conserve and maintain the green diversity, and could be further utilized for scientific validation [12]. During the 32nd session of United Nations Educational, Scientific and Cultural Organization (UNESCO), traditional knowledge on ethnoveterinary medicines was declared an important part of cultural heritage, which is required to be brought under study, sustenance, and protection [30].

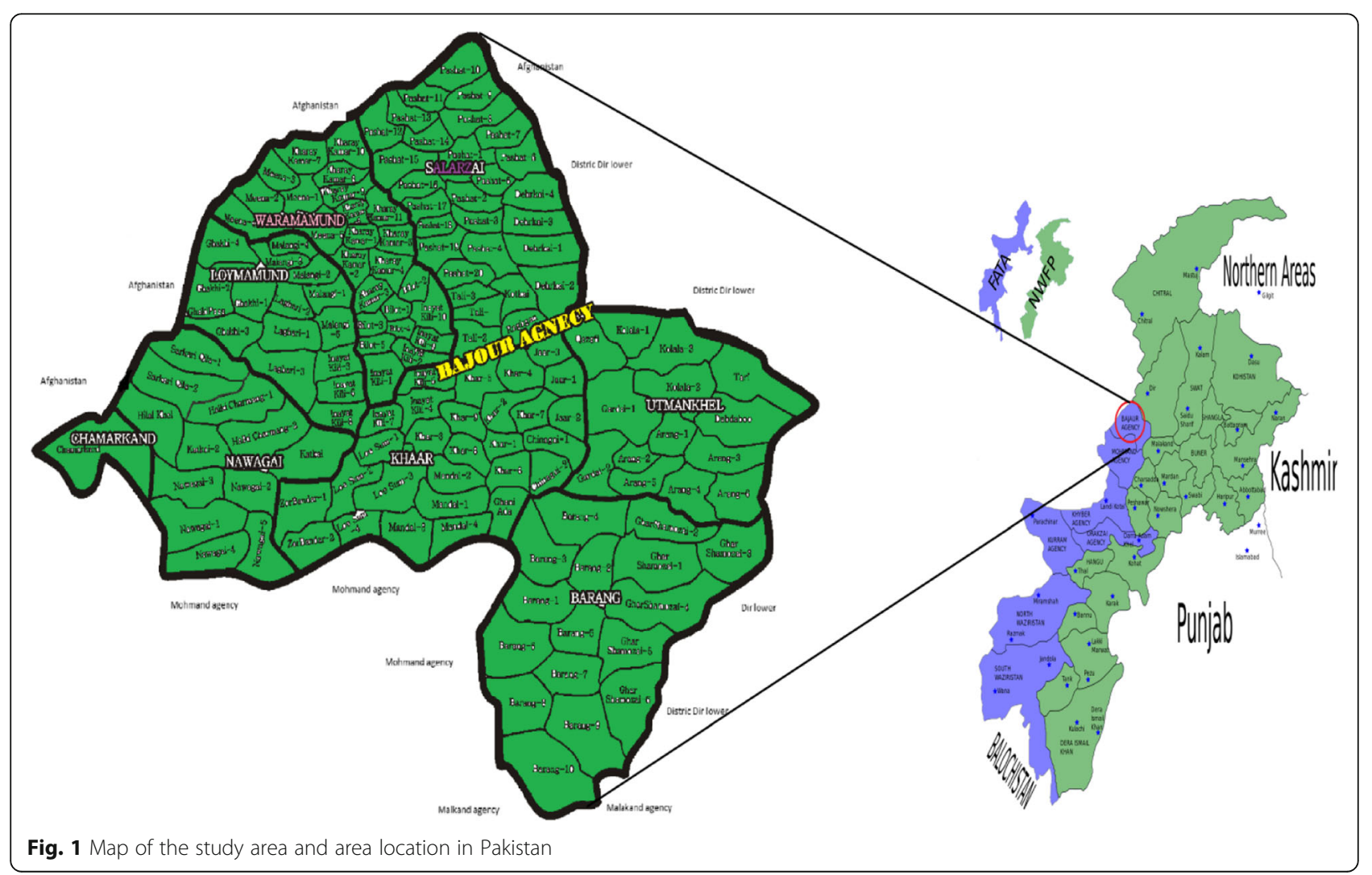


Table 1 Indicating the number and details of informants

\begin{tabular}{lll}
\hline Category & Total & $\%$ \\
\hline Gender & 68 & 85 \\
Male & 12 & 15 \\
Female & & \\
Age groups & 27 & 34 \\
$35-50$ & 53 & 66 \\
$>50$ & & \\
Occupation & 12 & 15 \\
House wives & 40 & 50 \\
Herders & 28 & 35 \\
Farmers & & \\
\hline
\end{tabular}

Indigenous communities at Bajaur Agency are dependent on livestock for supporting their livelihood. Medicinal plants have a pivot role in the treatment of livestock's ailments in the area. Usually, this treatment process depends either on the traditional knowledge being orally transmitted to the current generation of local people from their ancestors or through personal experiences. Previous scientific literature has focused on the correlation of traditional medical expertise to ethnobotanical knowledge for the treatment of human ailments [31, 32], although the same plants may be used to treat livestock [33, 34]. In our study, we have observed that the herders, farmers, and older community members are more equipped with traditional knowledge and familiar with veterinary medications, diagnosis process, and treatment.

Indigenous people of the study area are rich in traditional knowledge on veterinary medicines, which may be due to their close observation on domestic animals being considered as an important part of traditional lifestyle. Most commonly, the male community member grazes herds of animal, while females take part in households' management. Figures 2 and 3 showed some of the images of the grazed domestic animals, which are treated with medicinal plant in the area. Other studies have explained this in a different way that men due to close proximity tend to know more about the animal behavior than women [31].

People of the study area use plants not only for medicinal purposes to treat their domestic animals but also as a fodder. Local community also prevents their animals from such nutrition, which is not healthy in certain conditions and seasons. One may consider this prevention to be a part of ethnoveterinary practices. Nutrition is playing an important role in ethnoveterinary practices in both prevention and cure of domestic animals [35]. Livestock usually ingests some extra and non-important food substances in the green fodder, which could be termed as food medicines or medicinal food [36]. Studies have highlighted the importance of "food as medicines" in the context of local traditional knowledge; however, possible health advantages of food in ethnoveterinary methods need further attention [37]. Testing the nutritional status of each traditional ethnoveterinary remedy is not necessary; however, it is essential to evaluate the biological efficacy from the phytochemical, pharmacological, toxicological, and clinical perspectives for wider application. A considerable proportion of the documented uses of plant taxa in our study are in accordance with the established pharmacological effects [36].

The prevailing Indigenous ethnoveterinary knowledge in the study area is facing certain constrains leading it
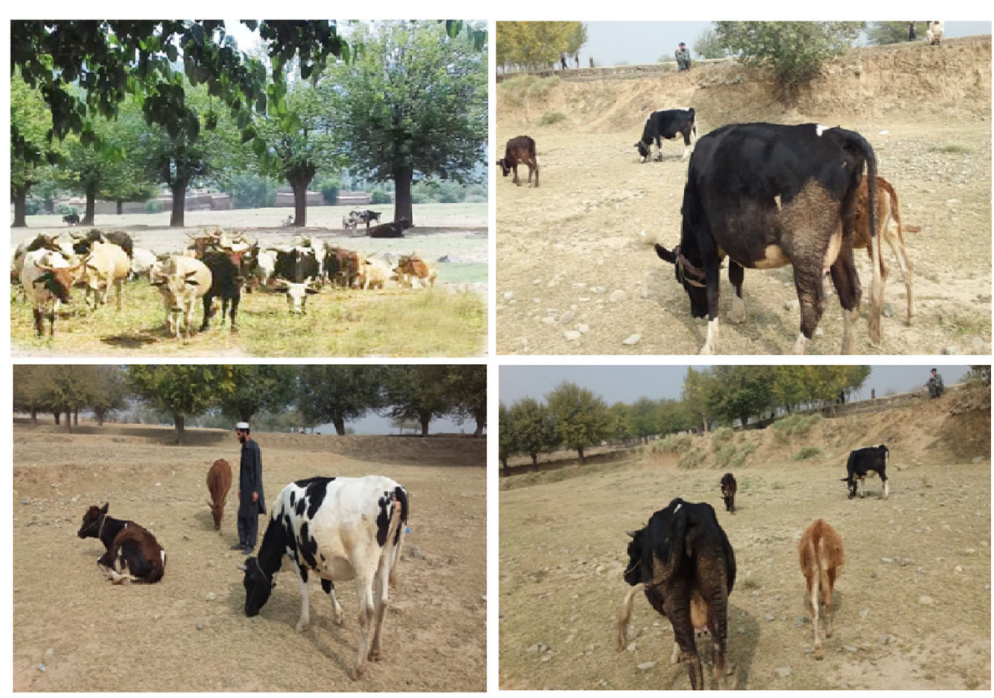

Fig. 2 Images of some of the animals treated with medicinal plants 


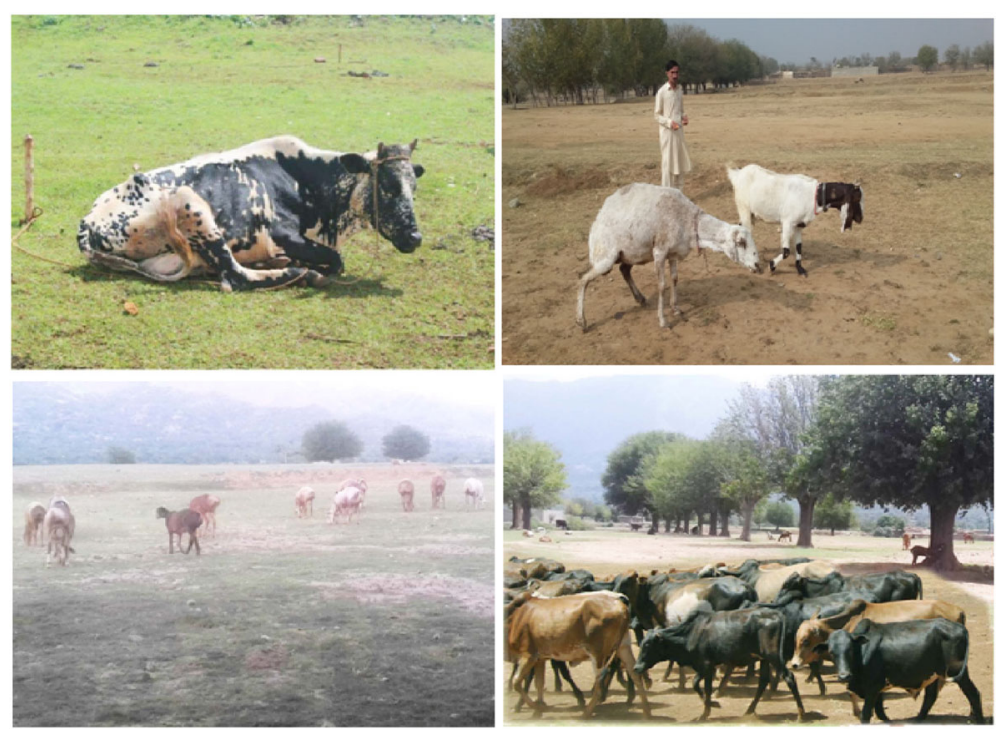

Fig. 3 Images of some of the animals treated with medicinal plants

towards extinction. As an example, the nature of traditional knowledge is making it more difficult to learn and then transfer it in an accurate way. Furthermore, practicing traditional therapies are not being respected by the new generation. Other challenges include low literacy rate in the study area, no proper documentation of Indigenous knowledge, and introduction of modern allopathic medicines, rapid technological advancement, and environmental degradation. Similar kinds of threats have also been reported in other communities across the world [38-40]. Informants with little education were found less familiar to the traditional knowledge while people having no formal education were more responsive in this regard. Some studies have found that education can be correlated with expertise either positively [41, 42] or negatively [43], while others found no relationship [44]. Moreover, it is also ambiguous to determine the effect of "modernity" on the loss of ethnomedicinal knowledge. Modernity has an established association with greater medicinal competence in Dominica [45] but appeared unrelated to variation in expertise among Tsimane horticulturalists in Bolivia [41]. Furthermore, it is also unclear whether correlation of expertise exists between ethnomedicinal knowledge and ethnoveterinary approaches; however, livestock keepers hold extensive knowledge related to disease prevention, diagnosis, and both traditional and novel biomedical treatments [26]. In summary, despite maintaining knowledge on ethnoveterinary practices by the locals, the tendency to utilize modern pharmaceuticals is increasing day by day. Hence, the conservation of ethnomedicinal knowledge by the local communities is extremely important for the livestock's health in the remote areas.

\section{Ethnoveterinary medications and their cross-cultural analysis with nearby regions}

The use of plants for medical purpose to treat a wide array of maladies emanates traces since the recorded history and even before. In our study, 73 plant species belonging to 43 families were documented. Table 2 presents details on the documented medicinal plants including their botanical names, vernacular names, family names, specimen numbers, parts used, medicinal uses, and use reports. Family Apiaceae (7 species) has the high number of individual species used in ethnoveterinary practices followed by Fabaceae ( 5 species). Other studies have also reported Apiaceae as the dominant plant family being used in traditional medications [37, 46]. The rationale of high use of Apiaceae species in the current study, though based on traditional evidence, may be referred to their chemical constituents such as phenolics, poly phenolics, lectins, alkaloids, terpenoids, and essential oils, which carry antimicrobial potential [47]. Due to the predominance of sheep, goats, cows, and donkeys in the study area, we have specifically recorded the ethnoveterinary practices used for the treatment of these four types of domestic animals. Key informants declared extensive uses of Visnaga daucoides Gaertn. (49 URs), followed by Foeniculum vulgare Mill. (47 URs), Solanum virginianum L. (43 URs), Withania somnifera (L.) Dunal (38 URs), Glycyrrhiza glabra L. (33 URs), and Curcuma longa L. (29 URs) (Table 2). Medicinal plants with high URs strengthen the concept that such species are more significant to the local population and useful in sharing the traditional knowledge with one another in the area. In our study, $V$. daucoides is used to treat diarrhea, abdominal pain, and retained placenta in domestic animals. 
Table 2 Medicinal uses of local flora for ethnoveterinary uses

\begin{tabular}{|c|c|c|c|c|c|}
\hline Family & Botanical name "voucher no." & $\begin{array}{l}\text { Plant local } \\
\text { name }\end{array}$ & Parts used & URs & Medicinal value \\
\hline Amaranthaceae & $\begin{array}{l}\text { Beta vulgaris } \mathrm{L} \text {. } \\
\text { "SBBU-33" }\end{array}$ & Choqandar & Whole plant & 6 & $\begin{array}{l}\text { A whole plant is subjected to powder } \\
\text { and is combined with flour and black } \\
\text { tea to treat digestive problems } \\
\text { especially in cow and buffalo. }\end{array}$ \\
\hline \multirow[t]{3}{*}{ Amaryllidaceae } & $\begin{array}{l}\text { Allium cepa L. } \\
\text { "SBBU-32" }\end{array}$ & Piaz & Bulb & 14 & $\begin{array}{l}\text { Bulb of the herb is crushed and } \\
\text { added milk for orally given to animals } \\
\text { ( } 6-8 \text { days) for curing digestive complaints. }\end{array}$ \\
\hline & $\begin{array}{l}\text { Allium sativum L. } \\
\text { "SBBU-16" }\end{array}$ & Oga & Bulb & 13 & $\begin{array}{l}\text { Bulb is crushed and mixed with way } \\
\text { to administered orally for several days } \\
\text { in order to rate of fertility in domestic } \\
\text { animals. }\end{array}$ \\
\hline & $\begin{array}{l}\text { Narcissus tazetta L. } \\
\text { "SBBU-59" }\end{array}$ & Gul-E-Nargas & Leaves & 10 & $\begin{array}{l}\text { Along with gurr and flour, fresh } \\
\text { leaves }(1 / 4 \mathrm{~kg}) \text { are boiled and orally } \\
\text { given to livestock for the retained } \\
\text { placental removal. }\end{array}$ \\
\hline \multirow[t]{7}{*}{ Apiaceae } & $\begin{array}{l}\text { Carum carvi L. } \\
\text { "SBBU-24" }\end{array}$ & Zeera & Fruit & 14 & $\begin{array}{l}\text { Tea is prepared from its fruit }(1 / 4 \mathrm{~kg}) \text {, } \\
\text { and then, it is combined with flour } \\
\text { and given to cattle for } 3 \text { days in order } \\
\text { to treat gastric problems. }\end{array}$ \\
\hline & $\begin{array}{l}\text { Cuminum cyminum L. } \\
\text { "SBBU-63" }\end{array}$ & Zankai & Fruit & 12 & $\begin{array}{l}\text { Half kilogram of fruit is boiled in black } \\
\text { tea and orally given for } 15-20 \text { days } \\
\text { on daily basis for the expulsion of } \\
\text { intestinal worms and treated gastric } \\
\text { problems. }\end{array}$ \\
\hline & $\begin{array}{l}\text { Eryngium biehersteinianum } \\
\text { (M. Bieb.) Nevski } \\
\text { "SBBU-5" }\end{array}$ & Yakandaz & $\begin{array}{l}\text { Stem and leaves } \\
\text { and stem }\end{array}$ & 23 & $\begin{array}{l}\text { Powder of its stem and leaves is } \\
\text { orally given for the treatment of } \\
\text { liver problems up to the duration } \\
\text { of } 8-12 \text { days. }\end{array}$ \\
\hline & $\begin{array}{l}\text { Foeniculum vulgare Mill. } \\
\text { "SBBU-61" }\end{array}$ & Kagelani & Fruit, leaves & 47 & $\begin{array}{l}\text { Decoction is made from it fresh } \\
\text { leaves and fruit ( } 150-200 \mathrm{~g}) \text {, and } \mathrm{t} \\
\text { hen, it is combined with gurr, } \\
\text { given orally to livestock for } \\
\text { appetite and as sedative for } \\
\text { the duration of } 5 \text { to } 6 \text { days. }\end{array}$ \\
\hline & $\begin{array}{l}\text { Heracleum candicans } \\
\text { Wall. ex DC. } \\
\text { "SBBU-17" }\end{array}$ & Skhwara & Roots & 13 & $\begin{array}{l}\text { Fresh root of the plant }(200 \mathrm{~g}) \text { is } \\
\text { combined with wheat flour and } \\
\text { made to paste which is orally given } \\
\text { to goat, cow, and sheep as sexual } \\
\text { tonic and to enhance the rate of } \\
\text { fertility up to } 3 \text { days. }\end{array}$ \\
\hline & $\begin{array}{l}\text { Trachyspermum ammi } \\
\text { (L.) Sprague } \\
\text { "SBBU-60" }\end{array}$ & Ajwain & Fruit & 19 & $\begin{array}{l}\text { Seeds }(1 / 4 \mathrm{~kg}) \text { of the plant, Allium cepa, } \\
\text { wheat flour, and Foeniculum vulgare } \\
\text { are thoroughly mixed. The resultant } \\
\text { blend is then orally given ( } 15 \text { days) } \\
\text { and is considered as good appetizer. }\end{array}$ \\
\hline & $\begin{array}{l}\text { Visnaga daucoides Gaertn. } \\
\text { "SBBU-48" }\end{array}$ & Sparkai & Fruit & 49 & $\begin{array}{l}\text { Tea is made from its fruit and given } \\
\text { orally to sheep, goat, cow, and buffalo } \\
\text { while treating diarrhea, abdominal } \\
\text { pain, and retained placenta. The } \\
\text { remedy is constantly utilized for } \\
\text { the duration of } 3 \text { days. }\end{array}$ \\
\hline \multirow[t]{2}{*}{ Apocynaceae } & $\begin{array}{l}\text { Calotropis procera } \\
\text { (Aiton) Dryand. } \\
\text { "SBBU-18" }\end{array}$ & Spalmai & Leaves & 21 & $\begin{array}{l}\text { Plants' fresh leaves are taken and } \\
\text { decoction is made, and after that, the } \\
\text { decoction is combined with "Ajuga } \\
\text { integrifolia" and is used for dermal } \\
\text { parasites for } 3 \text { to } 5 \text { days. }\end{array}$ \\
\hline & $\begin{array}{l}\text { Nerium oleander L. } \\
\text { "SBBU-22" }\end{array}$ & Gandiaray & Leaves & 19 & $\begin{array}{l}\text { To relieve the external parasite, the } \\
\text { decoction of its leaves is used for } \\
\text { animal bathing especially goat and cow. }\end{array}$ \\
\hline
\end{tabular}


Table 2 Medicinal uses of local flora for ethnoveterinary uses (Continued)

\begin{tabular}{|c|c|c|c|c|c|}
\hline Family & Botanical name "voucher no." & $\begin{array}{l}\text { Plant local } \\
\text { name }\end{array}$ & Parts used & URs & Medicinal value \\
\hline \multirow[t]{3}{*}{ Asteraceae } & $\begin{array}{l}\text { Artemisia absinthium L. } \\
\text { "SBBU-52" }\end{array}$ & Spara Botay & Whole plant & 5 & $\begin{array}{l}\text { Whole is subjected to powder and } \\
\text { mixed with gurr and wheat and is } \\
\text { used as anthelmintic. }\end{array}$ \\
\hline & $\begin{array}{l}\text { Artemisia scoparia } \\
\text { Waldst. \& Kit. } \\
\text { "SBBU-67" }\end{array}$ & Spara Botay & Leaves & 13 & $\begin{array}{l}\text { Decoction is made by taking } 1 / 2 \mathrm{~kg} \text { of } \\
\text { leaves which is mixed with gurr and } \\
\text { administered orally daily (for } 2 \text { to } 3 \text { days) } \\
\text { about } 1 \text { to } 2 \text { glasses for the treatment of } \\
\text { gastric complexities, blood purification, } \\
\text { and skin problems in goat, sheep, and } \\
\text { cow. }\end{array}$ \\
\hline & $\begin{array}{l}\text { Launaea procumbens (Roxb.) } \\
\text { Ramayya \& Rajagopal } \\
\text { "SBBU-44" }\end{array}$ & Shodapai & Whole plant & 9 & $\begin{array}{l}\text { Fresh plant is fed to animals, i.e., } \\
\text { goat, sheep, and cow as tonic and } \\
\text { galactagogue. }\end{array}$ \\
\hline Berberidaceae & $\begin{array}{l}\text { Berberis lycium Royle } \\
\text { "SBBU-42" }\end{array}$ & Koowary & Root & 24 & $\begin{array}{l}\text { Decoction is made from its root } \\
\text { (about } 1 / 4 \mathrm{~kg} \text { ) and is orally administered } \\
\text { to cattle ( } 10 \text { days) for the treatment } \\
\text { digestive tract infections, mouth } \\
\text { infections, refrigerant, and healing. }\end{array}$ \\
\hline Brassicaceae & $\begin{array}{l}\text { Brassica rapa } \mathrm{L} . \\
\text { "SBBU-39" }\end{array}$ & Sharsham & Oil & 28 & $\begin{array}{l}\text { Mustard oil }(75 \mathrm{ml}) \text { and whey are } \\
\text { mixed together and orally taken to } \\
\text { relieve abdominal pain. This is remedy } \\
\text { applied to cow and buffalo for the } \\
\text { duration of } 3 \text { days. }\end{array}$ \\
\hline Cactaceae & $\begin{array}{l}\text { Opuntia littoralis } \\
\text { (Engelm.) Cockerell } \\
\text { "SBBU-19" }\end{array}$ & Zoqam & Whole plant & 16 & $\begin{array}{l}\text { Powder is made from whole plant } \\
\text { and applied topically to all domestic } \\
\text { animals treat dermal problems, as } \\
\text { anti-inflammatory. }\end{array}$ \\
\hline \multirow[t]{2}{*}{ Cannabaceae } & $\begin{array}{l}\text { Cannabis sativa } \mathrm{L} \text {. } \\
\text { "SBBU-20" }\end{array}$ & Bang & Leaves, stem & 22 & $\begin{array}{l}\text { Leaves }(1 / 2 \mathrm{~kg}) \text { together with black tea } \\
\text { are boiled and then mixed with wheat } \\
\text { flour. This remedy is given to domestic } \\
\text { animals as refrigerant and also given to } \\
\text { the cattle suffering from genital prolapsed. }\end{array}$ \\
\hline & $\begin{array}{l}\text { Celtis australis L. } \\
\text { "SBBU-25" }\end{array}$ & Tagha & Bark & 8 & $\begin{array}{l}\text { Plants powder, ghee, and gurr are } \\
\text { combined together and given to cattle } \\
\text { twice a day (up to } 3 \text { days) for treating } \\
\text { digestive disorders. }\end{array}$ \\
\hline Chenopodiaceae & $\begin{array}{l}\text { Chenopodium album L. } \\
\text { "SBBU-35" }\end{array}$ & Sarmy & Whole plant & 17 & $\begin{array}{l}\text { About } 1 / 2 \mathrm{~kg} \text { leaves are taken and boiled } \\
\text { in mustard oil along with gurr, orally } \\
\text { taken by goat, sheep, cow, buffalo, and } \\
\text { donkey. This remedy is used as } \\
\text { stomachic. }\end{array}$ \\
\hline Convolvulaceae & $\begin{array}{l}\text { Convolvulus arvensis L. } \\
\text { "SBBU-31" }\end{array}$ & Perawaty & Whole plant & 13 & $\begin{array}{l}\text { Fresh leaves }(1 \mathrm{~kg}) \text { and gurr are boiled } \\
\text { in combination with black tea. This } \\
\text { remedy is given orally ( } 5-10 \text { days) for } \\
\text { milk production. }\end{array}$ \\
\hline Cupressaceae & $\begin{array}{l}\text { Chamaecyparis obtusa } \\
\text { (Siebold \& Zucc.) Endl. } \\
\text { "SBBU-40" }\end{array}$ & Saber Dana & Fruit & 9 & $\begin{array}{l}\text { Powder is made from its seeds and } \\
\text { makes black tea and then utilized to } \\
\text { heat the animals. This remedy is used } \\
\text { for buffalos and cows for } 3 \text { days. }\end{array}$ \\
\hline Cuscutaceae & $\begin{array}{l}\text { Cuscuta reflexa Roxb. } \\
\text { "SBBU-66" }\end{array}$ & Mecha & Whole plant & 8 & $\begin{array}{l}\text { First make a paste of leaves and then } \\
\text { combine with wheat flour. This remedy } \\
\text { is then given to goats and sheep } \\
(5-10 \text { days) as antispasmodic. }\end{array}$ \\
\hline Euphorbiaceae & $\begin{array}{l}\text { Ricinus communis L. } \\
\text { "SBBU-68" }\end{array}$ & Aranda & Oil & 15 & $\begin{array}{l}\text { Oil of its seed ( } 1 / 2 \text { cup) is administered } \\
\text { orally for the duration of } 1 \text { week. This } \\
\text { remedy is used as laxative and for the } \\
\text { treatment of diarrhea. }\end{array}$ \\
\hline
\end{tabular}


Table 2 Medicinal uses of local flora for ethnoveterinary uses (Continued)

\begin{tabular}{|c|c|c|c|c|c|}
\hline Family & Botanical name "voucher no." & $\begin{array}{l}\text { Plant local } \\
\text { name }\end{array}$ & Parts used & URs & Medicinal value \\
\hline \multirow[t]{5}{*}{ Fabaceae } & $\begin{array}{l}\text { Acacia modesta Wall. } \\
\text { "SBBU-27" }\end{array}$ & Palusa & Bark & 11 & $\begin{array}{l}\text { The decoction obtained from its bark } \\
\text { and is combined with butter which is } \\
\text { administered orally to all type of } \\
\text { domestic animals to treat skin } \\
\text { problems and as blood purifier. }\end{array}$ \\
\hline & $\begin{array}{l}\text { Cassia fistula L. } \\
\text { "SBBU-4" }\end{array}$ & Amaltas & Fruit & 13 & $\begin{array}{l}\text { Fruit of the plant is subjected to } \\
\text { boiling along with milk and } \\
\text { administered orally up to } 3 \text { days to all } \\
\text { sort of domestic cattle to relieve fever } \\
\text { and gastric complexities. }\end{array}$ \\
\hline & $\begin{array}{l}\text { Glycyrrhiza glabra L. } \\
\text { "SBBU-26" }\end{array}$ & Khwaga Waly & Roots & 33 & $\begin{array}{l}\text { Root }(1 / 4 \mathrm{~kg}) \text { is subjected to paste } \\
\text { which is mixed with flour and oil and } \\
\text { then is given to goat, sheep, cow, and } \\
\text { buffalo to increase milk production } \\
\text { and enhance the rate of fertility. The } \\
\text { remedy is used for the duration of } \\
5 \text { to } 7 \text { days. }\end{array}$ \\
\hline & $\begin{array}{l}\text { Lotus corniculatus L. } \\
\text { "SBBU-72" }\end{array}$ & FatiKhany & Stem and leaves, & 19 & $\begin{array}{l}\text { Stem and leaves are crushed in weight } \\
\text { of } 1 / 4 \mathrm{~kg} \text { and orally given to cattle along } \\
\text { with bread or dough for } 7 \text { to } 10 \text { days as } \\
\text { sexual tonic and for urinary tract } \\
\text { infections (UTI). }\end{array}$ \\
\hline & $\begin{array}{l}\text { Trigonella foenum-graecum L. } \\
\text { "SBBU-11" }\end{array}$ & Malkhoozi & Seeds & 9 & $\begin{array}{l}\text { Seeds ( } 150 \mathrm{~g} \text { ) are crushed and given in } \\
\text { dough to animals ( } 5-6 \text { days) against } \\
\text { gastric disorders. }\end{array}$ \\
\hline Fagaceae & $\begin{array}{l}\text { Quercus oblongata D. Don } \\
\text { "SBBU-7" }\end{array}$ & Tor batangar & Fruit & 22 & $\begin{array}{l}\text { Kernels of this plant are given to animal } \\
\text { for the entire cold season to keep the } \\
\text { animals energized. Skeletal problems } \\
\text { and internal infection are also treated by } \\
\text { utilizing the kernels. }\end{array}$ \\
\hline Juglandaceae & $\begin{array}{l}\text { Juglans regia L. } \\
\text { "SBBU-55" }\end{array}$ & Ghuz & Leaves & 18 & $\begin{array}{l}\text { Fresh leaves powder }(1 / 4 \mathrm{~kg}) \text { and gurr } \\
\text { are thoroughly mixed. This remedy is } \\
\text { orally taken and effective in gastric } \\
\text { disorders. }\end{array}$ \\
\hline \multirow[t]{4}{*}{ Lamiaceae } & $\begin{array}{l}\text { Ajuga integrifolia Buch. Ham. } \\
\text { ex D. Don } \\
\text { "SBBU-30" }\end{array}$ & Gutee & Leaves & 16 & $\begin{array}{l}\text { Decoction is made from the leaves } \\
\text { and then gurr is added. This remedy is } \\
\text { given orally to cattle for blood } \\
\text { purification and as vormifuge. The } \\
\text { water is applied topically to treat } \\
\text { skin ailments. }\end{array}$ \\
\hline & $\begin{array}{l}\text { Mentha spicata L } \\
\text { "SBBU-58" }\end{array}$ & Podina & Leaves and stem & 22 & $\begin{array}{l}\text { Powder is made and decoction is } \\
\text { made and then mixed with gurr and } \\
\text { taken by animals to cure digestive } \\
\text { problems. }\end{array}$ \\
\hline & $\begin{array}{l}\text { Ocimum basilicum L. } \\
\text { "SBBU-9" }\end{array}$ & Kashmaly & Leaves seed & 11 & $\begin{array}{l}\text { Plant leaves and seeds are subjected } \\
\text { to decoction and used topically for } \\
\text { skin problems. }\end{array}$ \\
\hline & $\begin{array}{l}\text { Salvia moorcroftiana Wall. } \\
\text { ex Benth. } \\
\text { "SBBU-13" }\end{array}$ & Kharghwag & Leaves & 9 & $\begin{array}{l}\text { Decoction of its leaves is given orally } \\
\text { daily for the treatment of digestive } \\
\text { problems. }\end{array}$ \\
\hline \multirow[t]{2}{*}{ Malvaceae } & $\begin{array}{l}\text { Gossypium arboreum L. } \\
\text { "SBBU-43" }\end{array}$ & Pomba & Kal & 11 & $\begin{array}{l}\text { About } 1 / 4 \mathrm{~kg} \text { of its powder is mixed } \\
\text { with gurr and used for } 10 \text { to } 12 \text { days. } \\
\text { This remedy is administered orally on } \\
\text { daily basis as galactagogue. }\end{array}$ \\
\hline & $\begin{array}{l}\text { Grewia optiva J.R.Drumm. } \\
\text { ex Burret } \\
\text { "SBBU-62" }\end{array}$ & Pastawony & Whole plant & 6 & $\begin{array}{l}\text { Dried plant powder is subjected to oil } \\
(250 \mathrm{ml}) \text {, administered orally and } \\
\text { topically twice a day for } 5 \text { to } 7 \text { days } \\
\text { for wound healing process. }\end{array}$ \\
\hline
\end{tabular}


Table 2 Medicinal uses of local flora for ethnoveterinary uses (Continued)

\begin{tabular}{|c|c|c|c|c|c|}
\hline Family & Botanical name "voucher no." & $\begin{array}{l}\text { Plant local } \\
\text { name }\end{array}$ & Parts used & URs & Medicinal value \\
\hline Meliaceae & $\begin{array}{l}\text { Melia azedarach L. } \\
\text { "SBBU-54" }\end{array}$ & Tora Bokana & Leaves & 15 & $\begin{array}{l}\text { Plant leaves ( } 200 \mathrm{~g} \text { ) are powdered and } \\
\text { then combined with sugar. This remedy } \\
\text { is orally given to cattle ( } 2-3 \text { days) against } \\
\text { gastric disorders. Diarrhea is also treated } \\
\text { by mixing the powder with flour cakes } \\
\text { of maize. }\end{array}$ \\
\hline \multirow[t]{2}{*}{ Moraceae } & $\begin{array}{l}\text { Ficus carica L. } \\
\text { "SBBU-73" }\end{array}$ & Inzar & Fruit and leaves, fruit & 16 & $\begin{array}{l}\text { Fresh leaves (about } 1 / 2 \mathrm{~kg} \text { ) are fed to } \\
\text { animals for digestive ailments and } \\
\text { disturbances. Fruit }(1 / 4 \mathrm{~kg} \text { ) is given two } \\
\text { times per day for placental removal. }\end{array}$ \\
\hline & $\begin{array}{l}\text { Streblus asper Lour. } \\
\text { "SBBU-14" }\end{array}$ & Tor tooth & Fruit & 12 & $\begin{array}{l}\text { Fruits }(2 \mathrm{~kg}) \text { are crushed by addition } \\
\text { of little quantity of water. This remedy } \\
\text { is given orally to livestock for } \\
\text { producing cooling effect. }\end{array}$ \\
\hline \multirow[t]{2}{*}{ Myrtaceae } & $\begin{array}{l}\text { Eucalyptus canaldulensis } \\
\text { Dehnh. } \\
\text { "SBBU-41" }\end{array}$ & Lachi & Leaves & 17 & $\begin{array}{l}\text { Leaves decoction and gurr are } \\
\text { thoroughly mixed and orally given } \\
\text { to cattle ( } 6-8 \text { days) against digestive } \\
\text { disorders and as appetizer. }\end{array}$ \\
\hline & $\begin{array}{l}\text { Myrtus communis L. } \\
\text { "SBBU-23" }\end{array}$ & Mano & Leaves & 18 & $\begin{array}{l}\text { Powder is made from it, and then, the } \\
\text { ground leaves are mixed with whey or } \\
\text { milk to treat digestive tract problems. }\end{array}$ \\
\hline Nyctaginaceae & $\begin{array}{l}\text { Boerhavia erecta L. } \\
\text { "SBBU-36" }\end{array}$ & Insut & Whole plant & 7 & $\begin{array}{l}\text { Gurr is mixed with the powder of the } \\
\text { plant which is locally known as "Paa" } \\
\text { and is topically applied to skin infections. }\end{array}$ \\
\hline Oleaceae & $\begin{array}{l}\text { Olea europaea L. } \\
\text { "SBBU-46" }\end{array}$ & Zytoon & Oil & 18 & $\begin{array}{l}\text { Oil is applied externally and emulsified } \\
\text { to inflamed areas and broken bones. } \\
\text { The oil is orally given for general body } \\
\text { improvement. }\end{array}$ \\
\hline Paeoniaceae & $\begin{array}{l}\text { Paeonia emodi Royle } \\
\text { "SBBU-69" }\end{array}$ & Mamekh & Fruit and rhizome & 18 & $\begin{array}{l}\text { Powder is made and combined with } \\
\text { flour which is used as tonic and for } \\
\text { the treatment of cough in goat and cow. }\end{array}$ \\
\hline Papaveraceae & $\begin{array}{l}\text { Papaver somniferum L. } \\
\text { "SBBU-15" }\end{array}$ & Koknar & Latex & 8 & $\begin{array}{l}\text { Latex is dried }(10 \mathrm{~g}) \text { and boiled in } \\
\text { black tea, which is an effective } \\
\text { analgesic remedy. Little dried latex } \\
\text { is combined with saliva and placed } \\
\text { on wound for blood clotting. }\end{array}$ \\
\hline Pedaliaceae & $\begin{array}{l}\text { Sesamum indicum L. } \\
\text { "SBBU-65" }\end{array}$ & Konzaly & Oil & 8 & $\begin{array}{l}\text { Oil of the plant is combined with } \\
\text { whey or milk and then given to } \\
\text { buffalo and cow for vaginal thrush. }\end{array}$ \\
\hline \multirow[t]{2}{*}{ Pinaceae } & $\begin{array}{l}\text { Cedrus deodara } \\
\text { (Roxb. ex D. Don) G. Don } \\
\text { "SBBU- } 45 \text { " }\end{array}$ & Nanzra & Oil & 19 & $\begin{array}{l}10-15 \text { plant oil drops are water mixed } \\
\text { for oral administration to goats, cows, } \\
\text { buffaloes, and sheep. This is the best } \\
\text { remedy for the removal of bad smell } \\
\text { of milk. The same recipe is also utilized } \\
\text { for gastric complexities and as cooling } \\
\text { agent. To depress the sexual ability of } \\
\text { the animals, oil in large quantity is } \\
\text { combined with water. }\end{array}$ \\
\hline & $\begin{array}{l}\text { Pinus roxburghii Sarg. } \\
\text { "SBBU-53" }\end{array}$ & Nakhtar & Latex & 13 & $\begin{array}{l}\text { Gums are water mixed and given to } \\
\text { buffaloes, cows, and sheep against } \\
\text { skin infections/allergies. }\end{array}$ \\
\hline Platanaceae & $\begin{array}{l}\text { Platanus orientalis L. } \\
\text { "SBBU-10" }\end{array}$ & Chinar & Bark & 14 & $\begin{array}{l}\text { Bark's powder, ghee, and milk are } \\
\text { mixed together and boiled. This } \\
\text { remedy is orally given to cattle against } \\
\text { gastric infections. }\end{array}$ \\
\hline Poaceae & $\begin{array}{l}\text { Oryza sativa } \mathrm{L} . \\
\text { "SBBU-28" }\end{array}$ & Chawal & Seed & 17 & $\begin{array}{l}\text { Seeds }(1 \mathrm{~kg}) \text { are water boiled with } \\
\text { yoghurt. The remedy is orally given to } \\
\text { cattle ( } 20-25 \text { days) as galactagogue. }\end{array}$ \\
\hline
\end{tabular}


Table 2 Medicinal uses of local flora for ethnoveterinary uses (Continued)

\begin{tabular}{|c|c|c|c|c|c|}
\hline Family & Botanical name "voucher no." & $\begin{array}{l}\text { Plant local } \\
\text { name }\end{array}$ & Parts used & URs & Medicinal value \\
\hline & $\begin{array}{l}\text { Triticum aestivum L. } \\
\text { "SBBU-51" }\end{array}$ & Ghanam & Seeds & 13 & $\begin{array}{l}\text { Gurr is boiled with flour }(1 / 4 \mathrm{~kg}) \text { and } \\
\text { then given to animals to enhance rate } \\
\text { of fertility ( } 10-12 \text { days). }\end{array}$ \\
\hline Polygonaceae & $\begin{array}{l}\text { Rumex hastatus D. Don } \\
\text { "SBBU-21" }\end{array}$ & Tarukay & Whole plant & 17 & $\begin{array}{l}\text { Root }(1 \mathrm{~kg}) \text { are taken and mixed with } \\
\text { the powder of bark of Quercus incana } \\
\text { and then boiled along with sugar and } \\
\text { flour which is traditionally recommended } \\
\text { for the treatment of UTI, digestive } \\
\text { problems, and wound healing. This } \\
\text { remedy is used for the duration of } 10 \text { to } \\
15 \text { days. }\end{array}$ \\
\hline Primulaceae & $\begin{array}{l}\text { Primula denticulata Sm. } \\
\text { "SBBU-37" }\end{array}$ & Mamera & Stem & 7 & $\begin{array}{l}\text { Stems' decoction is topically used } \\
\text { against eye infections. }\end{array}$ \\
\hline Ranunculaceae & $\begin{array}{l}\text { Nigella sativa } \mathrm{L} . \\
\text { "SBBU-34" }\end{array}$ & Kalonji & Seed & 16 & $\begin{array}{l}\text { Decoction is made from its seeds } \\
(100 \mathrm{~g}) \text { and given to cattle and } \\
\text { buffaloes as sexual tonic and general } \\
\text { body tonic. }\end{array}$ \\
\hline \multirow[t]{2}{*}{ Rhamnaceae } & $\begin{array}{l}\text { Zizyphus jujuba Mill. } \\
\text { "SBBU-6" }\end{array}$ & Baira & Fruit and leaves, & 17 & $\begin{array}{l}\text { Fresh leaves }(100 \mathrm{~g}) \text { decoction is orally } \\
\text { given }(2-3 \text { days) for the removal } \\
\text { worms. It is also used for gastric } \\
\text { troubles and as diuretic. }\end{array}$ \\
\hline & $\begin{array}{l}\text { Ziziphus oxyphylla Edgew. } \\
\text { "SBBU-8" }\end{array}$ & Elanai & Root & 15 & $\begin{array}{l}\text { Decoction (fresh roots) is useful against } \\
\text { liver infections in all types of } \\
\text { domesticated animals. }\end{array}$ \\
\hline \multirow[t]{2}{*}{ Rosaceae } & $\begin{array}{l}\text { Prunus armeniaca L. } \\
\text { "SBBU-2" }\end{array}$ & Khobanaiy & Gum & 9 & $\begin{array}{l}\text { Gums are boiled with ghee and then } \\
\text { powdered upon drying. Later on milk } \\
\text { is added for oral administration to cattle } \\
\text { for treating abdominal pain, for flatulence, } \\
\text { and as appetizer. }\end{array}$ \\
\hline & $\begin{array}{l}\text { Rosa moschata Herrm. } \\
\text { "SBBU-57" }\end{array}$ & Gulab & Flower & 12 & $\begin{array}{l}\text { Flowers }(100 \mathrm{~g}) \text { are taken in water, and } \\
\text { later, sugar milk are mixed into it. This } \\
\text { remedy is orally given to livestock to } \\
\text { produce anti-inflammation and anti- } \\
\text { congestion effect. }\end{array}$ \\
\hline Rutaceae & $\begin{array}{l}\text { Zanthoxylum armatum DC. } \\
\text { "SBBU-29" }\end{array}$ & Dambara & Fruit & 19 & $\begin{array}{l}\text { Fruits powder and wheat flour are } \\
\text { mixed and are used as antipyretic and } \\
\text { killing mouth germs. Fruits are also } \\
\text { considered as a good tonic for animals. } \\
\text { This plant is also feed to the animals } \\
\text { being suffered due to cold fever "local } \\
\text { name Charmakh." }\end{array}$ \\
\hline Salicaceae & $\begin{array}{l}\text { Salix tetrasperma Roxb. } \\
\text { "SBBU-47" }\end{array}$ & Wala & Bark & 16 & $\begin{array}{l}\text { Bark is crushed and cooked in ghee } \\
\text { then mixing it with flour of maize } \\
\text { which is given to all type of cattle to } \\
\text { treat cough and internal body infections. }\end{array}$ \\
\hline Simaroubaceae & $\begin{array}{l}\text { Ailanthus altissima } \\
\text { (Mill.) Swingle } \\
\text { "SBBU-50" }\end{array}$ & Speena Bokana & Leaves & 13 & $\begin{array}{l}\text { The leaves of the plant are used as } \\
\text { galactagogue. }\end{array}$ \\
\hline \multirow[t]{2}{*}{ Solanaceae } & $\begin{array}{l}\text { Nicotiana tabacum L. } \\
\text { "SBBU-70" }\end{array}$ & Tambacoo & Leaves & 20 & $\begin{array}{l}\text { Decoction is made from its leaves, and } \\
\text { then, it applied externally on animal's } \\
\text { body and then rubbed for external } \\
\text { parasites. Infusion of its leaves is } \\
\text { drenched via nostrils against leech } \\
\text { infestation in cows. }\end{array}$ \\
\hline & $\begin{array}{l}\text { Solanum virginianum L. } \\
\text { "SBBU-64" }\end{array}$ & Maraghuny & Roots, leaves, fruit & 43 & $\begin{array}{l}\text { Various parts of the plant are taken }(1 / 2 \mathrm{~kg}) \text {, } \\
\text { and then, decoction is made by adding } \\
\text { salt and yoghurt. This remedy is orally } \\
\text { given to cattle ( } 15-20 \text { days) against } \\
\text { cough, fever, and pain and for milk } \\
\text { production. }\end{array}$ \\
\hline
\end{tabular}


Table 2 Medicinal uses of local flora for ethnoveterinary uses (Continued)

\begin{tabular}{|c|c|c|c|c|c|}
\hline Family & Botanical name "voucher no." & $\begin{array}{l}\text { Plant local } \\
\text { name }\end{array}$ & Parts used & URs & Medicinal value \\
\hline & $\begin{array}{l}\text { Withania somnifera (L.) Dunal } \\
\text { "SBBU-38" }\end{array}$ & Kotilal & Leaves & 38 & $\begin{array}{l}\text { Roots and leaves are cooked in ghee } \\
\text { with gurr and then the resultant is } \\
\text { given to sheep, cow, and buffalo for } \\
\text { milk production. Also, it is used as } \\
\text { antipyretic and sexual tonic. }\end{array}$ \\
\hline Thymelaeaceae & $\begin{array}{l}\text { Daphne oleoides Schreb. } \\
\text { "SBBU-3" }\end{array}$ & Laighona & Leaves and flower & 6 & $\begin{array}{l}\text { Fresh leaves and flowers are taken and } \\
\text { are shaded dried for } 15 \text { days and } \\
\text { subjected to powder which is then } \\
\text { mixed with gurr and flour and given } \\
\text { to for the expulsion of worms to cattle } \\
\text { and buffalo. }\end{array}$ \\
\hline \multirow[t]{2}{*}{ Zingiberaceae } & $\begin{array}{l}\text { Curcuma longa L. } \\
\text { "SBBU-1" }\end{array}$ & Korkaman & Rhizome & 29 & $\begin{array}{l}\text { Rhizome is subjected to powder and } \\
\text { boiled in ghee. It is orally and topically } \\
\text { used } 2 \text { times per days ( } 5-10 \text { days) to } \\
\text { relieve external and internal parasite. } \\
\text { This is also used to treat genital infection } \\
\text { and problems. }\end{array}$ \\
\hline & $\begin{array}{l}\text { Zingiber officinale Roscoe } \\
\text { "SBBU-12" }\end{array}$ & Adrak & Root & 11 & $\begin{array}{l}\text { Rhizome }(80 \mathrm{~g}) \text { is grinded and combined } \\
\text { with gurr of } 500 \mathrm{~g} \text {. This mixture is then } \\
\text { boiled in } 2 \text { I of milk. This remedy is } \\
\text { traditionally considered useful for goats, } \\
\text { cows, and sheep (taken up to } 10 \text { days) } \\
\text { against digestive disorders, for flatulence } \\
\text { and as appetizer. }\end{array}$ \\
\hline \multirow[t]{2}{*}{ Zygophyllaceae } & $\begin{array}{l}\text { Peganum harmala L. } \\
\text { "SBBU-49" }\end{array}$ & Spalany & Seed, whole plant & 21 & $\begin{array}{l}\text { Fresh leaves (about } 1 / 2 \mathrm{~kg} \text { ) are burned, } \\
\text { and then with this smoke, animals are } \\
\text { fumigated to relieve external parasites. }\end{array}$ \\
\hline & $\begin{array}{l}\text { Tribulus terrestris } \mathrm{L} \text {. } \\
\text { "SBBU-56" }\end{array}$ & Azghakay & Leaves & 17 & $\begin{array}{l}\text { Leaves }(200 \mathrm{~g}) \text { of the plant are dried } \\
\text { and made powder of it and then mix } \\
\text { with the powder of Foeniculum vulgare } \\
\text { and administered orally to domestic } \\
\text { animals up to } 15 \text { days to treat digestive } \\
\text { problems. }\end{array}$ \\
\hline
\end{tabular}

The usage mode of ethnoveterinary plant species by one ethnic community is different from other communities due to difference in traditional knowledge [10, 15]. Previous literature has shown that decoction of the fruit of $V$. daucoides is used during abdominal pain, which is used to enhance body temperature in the study area [21, 48]. In the same way, the $F$. vulgare is considered as a strong appetite and sedative. In other cultures across the globe, $F$. vulgare is used for various livestock problems. For instance, this plant is effective in digestion and diarrhea, when mixed with Camellia sinensis, Trachyspermum ammi, ghee, and sugar [6, 21]. Pneumonia is also being treated by giving its seeds to the animals [24], while other uses include galactagogue and ruminative [49]. Various parts of $S$. virginianum are taken for the treatment of cough, fever, milk production, and pain. There is scarce literature on the use of $S$. virginianum as galactagogue, which shows the unique use of this plant species in the study area and familiarity of local population through longtime experiences. Published literature has indicated that the plant is also used for wound healing process [20] fever, cough, and intestinal infections [20]. Roots and leaves of W. somnifera are given to sheep, cow, and buffalo for milk production and used as antipyretic and sexual tonic. Indigenous populations comprising of various cultures residing in Lesser Himalayas (Pakistan) use W. somnifera for bovine mastitis [6], while in Ethiopia, this plant is being used to protect animals from bad evils [50]. The plant has carminative effects and is used to remove the flatulence [25]. Additionally, this plant is used as refrigerant and for abdominal pain, digestion, jaundice, skeletonmuscular ailments, and wound healing against sunstroke [26]; for treating diarrhea [22]; for trypanosomiasis [9]; and for anorexia [50]. Informant reported G. glabra as galactagogue and enhances the rate of fertility. Mussarat et al. [22] reported that this plant is culturally used for the treatment of cough by the Indigenous communities residing near the Indus River, Pakistan. However, from the literature, no conclusive evidence was found on the reported uses of G. glabra in our study. Such evidence-based observations could justify the idea of cultural diversity across the regional level in plant remedies. Previous studies related to the human's uses of G. glabra have demonstrates its effectiveness in the treatment of sex hormone imbalances and menopausal symptoms in women [51]. In the current investigation, rhizome of $C$. longa is used as 
antiparasitic and treating genital infection and problems. In other cultures, across the country, the dried rhizome of C. longa is mixed with eggs and given for mastitis [22], jaundice, and skeleton muscular ailments [26]. Decoction of its leaves is mixed sugar, which is used as wound healing agent $[6,19]$. A root of C. longa is used for hoof problems and sore joints [52]. In our study, the mustard oil is mixed with whey and is taken orally to relieve abdominal pain. The cultural ethnoveterinary uses from the Lesser Himalayas (Pakistan) include that the oil extracted from $B$. rapa seeds is utilized for stomach disorders, eye infection, and skin diseases [6]. Furthermore, Brassica rapa L. seeds are used for the retention of fetal membrane, while its oil is effective in treating genital prolepses and sores [53]. This plant is also used in placental retention and mastitis and as antiparasitic [19]; myiasis, mange, and helminthiasis [20]; and flatulence [49]. All these researchbased findings showed that the same medicinal plants are being used in different parts of the country; however, their uses differ from area to area and from culture to culture [48]. The ethnoveterinary plants use by one ethnic community is almost different from other communities due to several reasons. To make a comprehensive comparative cultural diversity analysis of plant utilization in ethnoveterinary practices, we have selected a study conducted by Aziz et al. [48] in the FATA region of Pakistan. In comparison, we have found that most widely used medicinal plant species in our study are $V$. daucoides, $F$. vulgare, $S$. virginianum, W. somnifera, G. glabra, and C. longa. While according to Aziz et al. [48], the ethnic communities in South Waziristan Agency are widely utilizing plant species such as B. rapa, Punica granatum, Capparis decidua, Mentha longifolia, Withania coagulans, and C. longa, during comparative analysis, it was found that only 15 medicinal plants were commonly used in both regions for ethnoveterinary practices, which include Acacia modesta Wall, Allium cepa L., Allium sativum L., B. rapa, Calotropis procera (Aiton) Dryand., Cannabis sativa L., Chenopodium album L. C. longa, F. vulgare, Juglans regia L., Nicotiana tabacum L., Peganum harmala L., Quercus oblongata D. Don, Trachyspermum ammi (L.) Sprague, and $V$. daucoides. Certain variations in the utilization of these plants and their parts were observed in both areas. For instance, the bulb of $A$. cepa is used as galactagogue by Waziristanian communities while in Bajaur, it is used to treat digestive problems. A. sativum is utilized for genital prolapsed while the same plant is used as sexual tonic for animals in Bajaur Agency. The seeds of B. rapa are widely used as appetizer and tonic and for cough, seasonal allergies, stomach disorders, and skin infections in South Waziristan Agency, while in the other region, it is used only against gastro-intestinal disorders. The Indigenous communities at South Waziristan Agency consider the leaves of $C$. procera useful in joint pain while on the other side, the residents of Bajaur Agency used the latex against skin problems. C. album is used for wound healing and flatulence at Waziristan while as stomachic at Bajaur Agency. J. regia is given for the retention of placenta at Waziristan while gastric problems in Bajaur. P. harmala is extensively used for gastrointestinal problems, as antiparasitic, and for skin diseases by Waziristanian communities, while it is used only for the riddance of external parasites in Bajaur. The possible reason for low consensus of the two regions in ethnoveterinary medicinal plants may be due to unique vegetation and distinct socio-cultural values.

According to a survey, out of 122 plant-derived pure compounds, $80 \%$ (94 plant species) were having the same potential as indicated in traditional medications [54]. As an example, galegine is obtained from Galega officinalis $\mathrm{L}$. and is used in the production of metformin and other bisguanidine-type anti-diabetic drugs [55]; khellin, extracted from $V$. daucoides., led to the development of cromolyn in the form of sodium cromoglycate, which is used as a bronchodilator; and papaverine isolated from Papaver somniferum forms the baseline for verapamil, which is generally utilized for hypertension [55]. Survey participants did not describe the standardized dosage and recovery time like other previous ethnoveterinary documentations. The main problem highlighted in other studies is the lack of accuracy in such ethnoveterinary practices, which also push the locals towards modern allopathic drugs for livestock health maintenance $[20,56]$. The main reason that veterinarian has always complained is the non-standardized dosage in traditional medicines. Though this is an accusation, one ethnomedicine does not mean that they lack efficacy but require standardization, which could benefit the traditional system by minimizing risks and toxicities. According to Kearns [57], ethnoveterinary medicines are facing a great intellectual challenge from social theory and postmodernism, and this challenge was focused while detecting variations in animal health practices, beliefs, and experiences of various social groups. Generally, it is not possible for all ethnoveterinary practices to be effective and, at the same time, they have certain weakness in terms of their efficacy as compared to modern medications [58]. Though it is convincing that most of the traditional veterinary medications have clear and sound health effects, many modern allopathic drugs are based on these medicines [59].

Certain plants in our study were used in single form for more than one disease. For example, Cedrus deodara (Roxb. ex D. Don) G. Don is used in a condition, in which milk obtained from the cattle gives bad smell, then the oil is given orally to the cattle. It is also used as a cooling agent and in treating digestive problems. In large quantity, the oil have the potential to depress the sexual power of male animals [49]. Monteiro et al. [60] also reported similar findings from Pakistan and Brazil, 
respectively, where they described multiple uses of a single medicinal plant. Utilization of certain plant species for multiple diseases is a widespread practice in ethnoveterinary medications. In contrast, some ethnoveterinary remedies (polyherbal formulations) are being made by combing two or more plants and additives such as whey, ghee, and sugar. This addition is generally followed in remedies to counteract the astringent taste, dilute, and reduce the relative potency of the remedy [61].

\section{Ethnoveterinary disease category}

In the study area, a total of 32 plants were reported for gastrointestinal problems with maximum use reports of 433 (Table 3), which is regarded as the most common disease category in domestic animals being represented by abdominal pain, diarrhea, and digestive problems. These health issues can be easily detected by the respondents and may explain the fact that why the gastric problem category is high in ours as well as in others studies. Different ailments were categorized into 10 groups such as dermatological, gastrointestinal, galactagogue, reproductive, respiratory disorders, tonic, wound healing fever, and miscellaneous. Those medical conditions, which were not fully described by the interviewees, were placed into the miscellaneous category. These include eye problems, weakness, and abnormal conditions related to various organ systems of animal bodies. Highest Fic values were recorded for dermatological problems (0.97) followed by reproductive ailments (0.93) and gastric disorders (0.92) (Table 3). Fic value is an indicator of showing the consent of the local people on a specific plant species and efficacy of a certain taxa [62]. Sharma et al. [63] declared that when Fic becomes 1, it means that the local population is exchanging their view, ideas, and information about traditional medications, while on the other side, if the Fic value is 0 , then it is vice versa. Fic value in the current study was recorded in between 0.85 and 0.97 for various livestock ailments (Table 3). These findings

Table 3 Category wise informant consensus factor (Fic) (Bajaur Agency)

\begin{tabular}{llll}
\hline Medical categories & Number of species & Citations & Fic \\
\hline Tonic & 5 & 38 & 0.89 \\
Dermatological & 4 & 120 & 0.97 \\
Gastrointestinal & 32 & 433 & 0.92 \\
Galactagogue & 8 & 86 & 0.91 \\
Reproductive & 11 & 155 & 0.93 \\
Miscellaneous & 22 & 201 & 0.89 \\
Respiratory disorders & 4 & 37 & 0.91 \\
Fever & 5 & 41 & 0.90 \\
Wound healing & 7 & 41 & 0.85 \\
\hline
\end{tabular}

indicate the highest consent among the local people on traditional herbal therapies. Previous research studies conducted in other areas also agreed to high consent of local people on traditional animal therapies. For instance, the reported Fic values for dermatological problems were $0.93,0.93$, and $0.82[26,64,65]$; for reproductive disorders, 1.00 and 0.89 [65, 66]; for gastric problems, 0.90, 0.70, 0.92, 0.95, and 0.94 [26, 64-66]; for galactagogue, 0.83 and 0.50 [6, 65]; and for wound healing, 0.40 and $0.45[6,67]$. Heinrich et al. [68] has submitted the idea that high Fic values can be used as a tool to target the plants for the isolation of biologically active components. In our study, most livestock's ailments were mentioned to be seasonal and epidemic due to change in fodder. Furthermore, the concept of hot and cold food is also famous in order to prevent animals from diseases. The local residents change the relative fodder in different seasons in order to minimize the chances of various health problems in cattle. As an example, the seeds of the Nigella sativa L. and kernels of Q. oblongata are given to the cattle to energize them during the cold season. Similarly, the fruits of the Streblus asper Lour. produce cooling effects and considered to be a better remedy during hot summer season. In the same manner, local communities tend to give the infusion of Cannabis sativa $\mathrm{L}$ to their livestock in the summer season. Quinlan [69] and Raziq et al. [9] has also mentioned the concept of hot and cold food in traditional veterinary medications.

\section{Pharmacological evidences}

Drugs derived from plants or their extracts have certain therapeutic properties. To replace antibiotics by suitable therapeutic agents, plants can play an important role in combating with bacterial pathogens. There are several essential oils, which can be used as alternate of antibiotics. These oils can be easily isolated, having low toxicity on mammalian cells, and can be easily degraded in soil and water [70]. In this section, we will analyze the pharmacological evidences of the most utilized studied medicinal plant species in order to check their therapeutic efficacy.

In $F$. vulgare, phenols, phenolic glycosides, and volatile aroma compounds such as transanethole, estragole, and fenchone are reportedly the key phytoconstituents and responsible for its antioxidant activity. F. vulgare is pharmacologically validated (in vitro and in vivo) in demonstrating activities such as antibacterial, antifungal, antioxidant, antithrombotic, and hepatoprotective [71]. By investigation, it was found that the leaf extracts of $S$. virginianum is more active against Candida albicans, Salmonella typhi, Staphylococcus aureus, and nematodes $[72,73]$. For various extracts obtained in alcohol and water, it was found that W. somnifera has antibacterial 
potential, antihypercholesterolemic activities as well as diuretic potential [72, 74].

It has been reported that alcoholic and aqueous extracts of C. longa have shown antibacterial activity [74] while its ethanol, petroleum, water, and chloroform extracts are effective against certain strains of viruses, bacteria, and fungi and also have shown anti-inflammatory effects [75]. Researchers have claimed that plant-derived medicines used in traditional systems across the globe can be used as an indicator to consider them more effective than modern drugs [6]. Livestock keepers are using several plant-derived remedies for various acute as well as chronic disorders of cattle. Plant-derived medicines have been used by physicians for hundreds of years in traditional systems, and most of the world population rely on these products for health care systems [76]. There are several thousand plants across the globe being utilized for various therapeutic purposes both animals and humans [49]. Out of these medicinal plants, very low proportion has been investigated and proved scientifically for their Indigenous uses [77]. The essential oils in medicinal plants are having strong antimicrobial potential. As an example, essential oils of cinnamon, thyme, and oregano are therapeutically effective [78].

Antibiotic resistance is an emerging global concern related to veterinary and human medications [79]. Hence, it is necessary to search for new compounds to combat antibiotic resistant bacteria. Improper therapeutic utilization of antimicrobial medicines in fishery, poultry, agriculture, and animal farming facilitates the emergence and production of drug resistant strains. Additionally, poor prevention and control of unhygienic practices contribute in resistance emergence. The World Health Organization, Food and Agriculture Organization, and World Organization for Animal Health are stressing to promote best practices to avoid the emergence and spread of antibacterial resistance. Continuous attempts are in progress to promote the moderate use of antibiotics in human as well as in animals to tackle the problem of antimicrobial drug resistance [80].

In general, plants should be used as an alternative to synthetic drugs and investigated for their therapeutic efficacy. Certain plants in our study including Boerhavia erecta L., Celtis australis L., Chamaecyparis obtusa (Siebold \& Zucc.) Endl., Eryngium biehersteinianum (M. Bieb.), Gossypium arboreum L., H. candicans Wall. ex DC., Narcissus tazetta L., Opuntia littoralis (Engelm.) Cockerell, and S. asper need comprehensive phytochemical, pharmacological, and toxicological investigations.

\section{Current study, one health concept, and changing environment}

Current study reports that there are several ailments being treated with medicinal plants by the Indigenous populations. Most prevalent disease categories were dermatological, reproductive, and gastric problems. The dominance of these diseases not only poses threats to the domestic animals but also increases the chances of zoonoses. Local population uses various animal products; hence, there are maximum chances of the migration of infectious diseases from these animals to humans. Linkage of the ethnoveterinary studies with the researches of other disciplines may form an interdisciplinary approach to combat several types of health issues in both animals and plants. This approach mainly led to the concept of one health, which contributes towards understanding the complexities in health problems of living beings [81]. A recent surge in emerging infectious diseases and their putative associated costs to society have reignited interest in the drive of disease emergence. A number of pathogens have emerged in the last 20 years, including the severe acute respiratory syndrome virus, Hendra virus, and Nipah virus. However, there is a growing concern about the $\mathrm{H}_{5} \mathrm{~N}_{1}$ influenza virus, which fuelled much of the recent debate around emerging infectious diseases (EIDs) [82]. One of the benefits that accrued from the attention on EIDs has been an increased recognition across a range of disciplines that the health of animals (including humans) and the health of the broader ecosystem are inextricably linked, which certainly given momentum to One Health movement. One Health is not all about EIDs, but it also covers important issues of food security and food safety [83]. There is a strong consensus that the climate is changing now and that human activities are the primary cause [84]. However, it is clear that climate change will alter the distribution and incidence of a wide range of diseases either directly or indirectly (e.g., diseases with a development stage outside the host) $[85,86]$. The pathways by which climate change can affect host pathogen vector interactions have recently been well described by Gallana et al et al. [86].

One Health Initiative Task Force (OHITF) [87] defines one health as "the promotion, improvement, and defense for the health and well being of all species by enhancing cooperation and collaboration between physicians, veterinarians, and other scientific health professionals and by promoting strengths in leadership and management to achieve these goals". The one health approach plays a significant role in the prevention and control of zoonoses. Approximately $75 \%$ of new emerging human infectious diseases are defined as zoonotic $[79,88]$. Of the 1461 infectious diseases, approximately $60 \%$ are caused by multi-host pathogens, characterized by their movement across various species [89]. This gives significant credence to the importance of examining health effects across species, in order to fully understand the public health and economic impact of such diseases and to help implement treatment and preventive programs. 
The application of one health approach has been recognized as a critical need by international organizations as well as the preferred approach to address global health issues. It is also noted that knowledge in veterinary medicine and animal nutrition and husbandry could provide insights into human nutrition and growth.

\section{Biodiversity concerns}

It is a widespread phenomenon that natural resources including plants are always prone to threats in their natural habitat due to rapid human intervention and destructions of natural resources. The collection process of medicinal plants for ethnic practices and other anthropogenic practices is not only destructing the Indigenous flora but also posing a threat to the traditional knowledge. UNESCO has emphasized on the documentation and preservation of traditional knowledge in South Asia generally and Pakistan and India particularly. However, efforts are going on but they are not sufficient for the conservation of traditional knowledge persistent since several centuries, which can lead to valuable discoveries in modern healthcare system. The local perception of Indigenous communities regarding the threats being faced to the ecological resources especially the medicinal plants was examined in the current study. The lack of awareness has been observed as a major threat to the conservation of plant resources. It was also observed that different factors including time of collection, processing, storage, and herbal preparations are important and necessary steps to be considered for both economic returns and conservation. Mainly, the local healers are involved in the collection of medicinal plants. A study in the Swat region of Pakistan has shown that higher economic outcomes can be obtained from proper harvesting of wild medicinal plants as compared to the standard cash crop [90]. Other studies are supporting our results by showing an enormous potential in improving the harvesting, storage, use, preparation, and marketing of the herbal product as a source of income [91]. In the remote areas of the study region, local inhabitants obtained significant economic advantages from forest products. Similar advantages have been reported for other mountainous communities in the northern parts of Pakistan [26].

There are certain other threats to the medicinal plant resources of the study area, which include deforestation, heavy grazing pressure, uncontrolled collection of fodder, and other non-timber forest products by the local people and traders. Several studies have reported a decrease in the number of medicinal plants due to over exploitation and environmental degradation [92, 93]. It is therefore a dire need to manage and design the overall grazing system to encourage the sustainable regeneration and protection of medicinal plants. Keeping the observation and findings of the current investigation, proper management steps should be taken with the active participation from the Indigenous communities to conserve this precious flora. It is also important to aware the local people about the market value and sustainable harvesting of medicinal plants. Rapid modernization and urbanization is not only a threat for plant species' degradation but also a threat for the associated folk knowledge. That is why that the disappearance of folk knowledge has been declared more in danger than the natural resources themselves [94]. Therefore, we present a strong recommendation that ethnobotany as a subject should be included into the curriculum to help students in recognizing the endangered and medicinally important species of their respective regions. In addition, incentives may be given to farmers for the cultivation of medicinal plants on marginal lands and home gardens.

\section{Conclusions}

Indigenous communities at Bajaur Agency are dependent on medicinal plants for ethnoveterinary practices. Knowledge about the traditional medicinal system is restricted to the herders, farmers, and elder community members. The younger generation is unaware of this traditional treasure and takes no interest due to modernization. Hence, this study is an attempt towards the preservation of traditional ethnoveterinary knowledge from being extinct. There are several medicinal plants, which are being used in traditional herbal system of veterinary disorders. Some of the important are $V$. daucoides, F. vulgare, S. virginianum, W. somnifera, G. glabra, and C. longa. New ethnoveterinary uses used at the study area were found for H. candicans and G. glabra. Apiaceae is utmost plant family being in use for various livestock ailments. Thorough phytochemical and pharmacological investigations are required by isolating the active compounds and testing the in vitro or in vivo efficacy of the abovementioned plants against the targeted veterinary diseases. Furthermore, critical toxicological investigations are also required to ensure the safe and secure use of documented ethnomedicines. In order to share and further maintain this knowledge, it is direly needed to aware the rural population about the significance of traditional ethnoveterinary knowledge and to motivate them on the conservation of natural flora.

\section{Abbreviations \\ EIDs: Emerging infectious diseases; FATA: Federally administrated tribal areas; Fic: Informant consensus factor; GDP: Gross domestic product; OHITF: One Health Initiative Task Force; UNESCO: United Nations Educational, Scientific and Cultural Organization; URs: Use reports}

\section{Acknowledgements}

The authors extend their high appreciation and acknowledgment towards the local communities by providing moral support to the authors.

Funding

This research study did not receive any grant from any organization. 


\section{Availability of data and materials}

Data gathered during the course of the study has been included in the article.

\begin{abstract}
Authors' contributions
AHK and HU conducted the field work. MAA wrote the draft manuscript. AHK and HU helped in the compilation of data. MA gave technical comments on the draft and indicated the language and grammatical mistakes. MAA and MA supervised all the stages. All the authors read and approved the manuscript.
\end{abstract}

\section{Ethics approval and consent to participate}

Not applicable

\section{Consent for publication}

Not applicable

\section{Competing interests}

The authors declare that they have no competing interests.

\section{Publisher's Note}

Springer Nature remains neutral with regard to jurisdictional claims in published maps and institutional affiliations.

\section{Author details}

'Department of Botany, Kohat University of Science and Technology, Kohat 26000, Pakistan. ${ }^{2}$ Department of Botany, Shaheed Benazir Bhuto University Sheringal, District Dir (Upper) 18000, Pakistan. ${ }^{3}$ Department of Zoology, Abdul Wali Khan University, Mardan 23200, Pakistan.

\section{Received: 16 July 2017 Accepted: 16 January 2018}

\section{Published online: 29 January 2018}

\section{References}

1. McCorkle CM, Green EC. Intersectoral health care delivery. Agric Hum. 1998; 15:105-14.

2. Lans C, Turner N, Khan T, Brauer G, Boepple W. Ethnoveterinary medicines used for ruminants in British Columbia, Canada. J Ethnobiol Ethnomed. 2007:3:11

3. Dilshad SMR, Rehman NU, Ahmad N, labal A. Documentation of ethnoveterinary practices for mastitis in dairy animals in Pakistan. Pak Vet J. 2010:30:167-71.

4. FAO. Genetics and animal health Spotlight. Rome: FAO; 2002.

5. Pica-Ciamarra U, Baker D, Morgan N, Zezza A. Meas. contribution livest. househ. livelihoods: a livest. module multi-topic househ. surv. 2011.

6. Abbasi AM, Khan SM, Ahmad M, Khan MA, Quave CL, Pieroni A. Botanical ethnoveterinary therapies in three districts of the Lesser Himalayas of Pakistan. J Ethnobiol Ethnomed. 2013;9:1-21.

7. Sarwar M, Khan MA, Nisa M, labal Z. Dairy industry in Pakistan: a scenario. Int J Agric Biol. 2002;4:420-8.

8. Economic Survey of Pakistan. Government of Pakistan (GoP), finance division, economic advisor wing, Islamabad. 2010.

9. Raziq A, Verdier K, Younas M. Ethnoveterinary treatments by dromedary camel herders in the Suleiman Mountainous Region in Pakistan. An observation and questionnaire study. J Ethnobiol Ethnomed. 2010;6:16.

10. Eswaran S, Boomibalagan P, Rathinavel S. Ethnoveterinary medicinal practices of the villagers of Usilampatti Taluk of Madurai district, India. Int J Bot. 2013;9:37-43.

11. Galav P, Jain A, Katewa SS. Ethnoveterinary medicines used by tribals of Tadgarh-Raoli wildlife sanctuary, Rajasthan, India. Indian J Tradit Knowl. 2013;12:56-61.

12. Mishra D. Cattle wounds and ethnoveterinary medicine: a study in Polasara block, Ganjam district, Orissa India Indian. J Tradit Knowl. 2013;12:62-5.

13. Mallik BK, Panda T, Padhy RN. Ethnoveterinary practices of aborigine tribes in Odisha, India. Asian Pac J Trop Biomed. 2012;2:1520-5.

14. Pragada PM, Rao GMN. Ethnoveterinary medicinal practices in tribal regions of Andhra Pradesh, India. Bangl J Plant Taxon. 2012;19:7-16.

15. Bharati KA, Sharma BL. Plants used as ethnoveterinary medicines in Sikkim Himalayas. Ethno Bot Res. 2012;10:339-56.

16. Phondani PC, Maikhuri RK, Kala CP. Ethnoveterinary uses of medicinal plants among traditional herbal healers in Alaknanda catchment of Uttarakhand, India. Afr J Tradit Complement Altern Med. 2010;7:195-206.
17. Maiti S, Chakravarty P, Garai S, Bandyopadhyay S, Chouhan VS. Ethno-veterinary practices for ephemeral fever of Yak. A participatory assessment by the Monpa tribe of Arunachal Pradesh. Indian J Tradit Knowl. 2013;12:36-9.

18. Selvaraju A, Ayyanar M, Rathinakumar SS, Sekar T. Plants used in ethnoveterinary medicine by malayalitribals in Salem district of Tamil Nadu, India. Medicinal Plants. 2011;3:209-15.

19. Tariq A, Mussarat $S$, Adnan M, Naser M, AbdElsalam Ullah R, Khan AL. Ethnoveterinary study of medicinal plants in a tribal society of Sulaiman Range. Scientific World J. 2014:Article ID 127526. 10 pages https://doi. org/10.1155/2014/127526.

20. Farooq Z, lqbal Z, Mushtaq S, Muhammad G, lqbal MZ, Arshad M. Ethno veterinary practices for the treatment of parasitic diseases in livestock in Cholistan desert Pakistan. J Ethnopharmacol. 2008:118:213-9.

21. UI Hassan H, Murad W, Tariq A, Ahmad A. Ethnoveterinary study of medicinal plants in Malakand Valley, District Dir (Lower), Khyber Pakhtunkhwa, Pakistan. Ir Vet J. 2014;67:6.

22. Mussarat S, Amber R, Tariq A, Adnan M, AbdElsalam NM, Ullah R, Bibi R. Ethnopharmacological assessment of medicinal plants used against livestock infections by the people living around Indus river. Biomed Res Int. 2014;2014:1-14.

23. Khan MA, Khan MA, Hussain $\mathrm{H}$. Ethnoveterinary medicinal uses of plants of Poonch valley Azad Kashmir. Pak J Weed Sci Res. 2012;18:495-507.

24. Sindhu ZUD, Iqbal Z, Khan MN, Jonsson NN, Siddique M. Documentation of ethnoveterinary practices used for treatment of different ailments in a selected hilly area of Pakistan. Int J Agri Bio. 2010;12:353-8.

25. Khattak NS, Nouroz F, Rahman NU, Noreen S. Ethno veterinary uses of medicinal plants of district Karak, Pakistan. J Ethnopharmacol. 2015;171:273-9.

26. Ahmad K, Ahmad M, Weckerle C. Ethnoveterinary medicinal plant knowledge and practice among the tribal communities of Thakht-eSulaiman Hills, West Pakistan. J Ethnopharmacol. 2015;170:275-83.

27. Martin GJ. Ethnobotany. A methods manual. London: Chapman and Hall; 1995

28. Ali S I, Nasir YJ (Eds.). Flora of Pakistan. Nos. 191-193. Department of Botany. University of Karachi and National Herbarium, PARC, Islamabad Pakistan. 1989-1991.

29. Ali Sl, Qaiser M (Eds.). Flora of Pakistan. Nos. 194-218. Department of Botany, University of Karachi, Pakistan. 1993-2011.

30. Suroowan S, Javeed F, Ahmad M, Zafar M, Noor MJ, Kayani S, Javed A, Mahomoodally MF. Ethnoveterinary health management practices using medicinal plants in South Asia—a review. Vet Res Commun. 2017:41:147-68.

31. Giovannini P, Reyes-García V, Waldstein A, Heinrich M. Do pharmaceuticals displace local knowledge and use of medicinal plants? Estimates from a cross-sectional study in a rural indigenous community, Mexico. Soc Sci Med. 2011;72:928-36.

32. Flores KE, Quinlan MB. Ethnomedicine of menstruation in rural Dominica, West Indies. J Ethnopharmacol. 2014;153:624-34.

33. Souto $T$, Ticktin $T$. Understanding interrelationships among predictors (age, gender, and origin) of local ecological knowledge. J Econ Bot. 2012;66:149-64.

34. Gakuubi MM, Wanzala W. A survey of plants and plant products traditionally used in livestock health management in Buuri district, Meru County, Kenya. J Ethnobiol Ethnomed. 2012;8:39.

35. Ogle BM, Tuyet HT, Duyet HN, Xuan Dung NN. Food, feed or medicine: the multiple functions of edible wild plants in Vietnam. Econ Bot. 2003:57:103-17.

36. Disler M, Ivemeyer S, Hamburger M, Vogl CR, Tesic A, Klarer F, Meier B, Walkenhorst M. Ethnoveterinary herbal remedies used by farmers in four north-eastern Swiss cantons (St. Gallen, Thurgau, Appenzell Innerrhoden and Appenzell Ausserrhoden). J Ethnobiol Ethnomed. 2014;10:32.

37. Pieroni A, Giusti ME, De Pasquale C, Lenzarini C, Censorii E, Gonzáles-Tejero MR, Sánchez-Rojas CP, Ramiro-Gutiérrez JM, Skoula M, Johnson C, Sarpaki A. Circum-Mediterranean cultural heritage and medicinal plant uses in traditional animal healthcare: a field survey in eight selected areas within the RUBIA project. J Ethnobiol Ethnomed. 2006;2(1):16.

38. Liu YC, Dao ZL, Yang CY, Liu YT, Long CL. Medicinal plants used by Tibetans in Shangri-la, Yunnan, China. J Ethnobiol Ethnomed. 2009:5:15.

39. Shen SC, Wilkes A, Huang YL. Discussion on the institutionalization of participatory livestock technological development. Guizhou Agricultural Sciences. 2007;35(2):107-11.

40. Vandebroek I, Thomas E, Sanca S, Damme PV, Puyvelde LV, Kimpe ND. Comparison of health conditions treated with traditional and biomedical health care in a Quechua community in rural Bolivia. J Ethnobiol Ethnomed. 2008:4:1. 
41. Reyes-García V, Vadez V, Byron E, Apaza L, Leonard WR, Perez E, Wilkie D. Market economy and the loss of folk knowledge of plant uses: estimates from the Tsimane' of the Bolivian Amazon. J Anthropol. 2005;46:651-6.

42. Ruiz-Mallén I, Barraza L, Bodenhorn B, Reyes-García V. School and local environmental knowledge, what are the links? A case study among indigenous adolescents in Oaxaca, Mexico. Int Res Geogr Environ Educ. 2009;18:82-96

43. Reyes-García V, Kightley E, Ruiz-Mallén I, Fuentes-Peláez N, Demps K, Huanca T, Martínez-Rodríguez MR. Schooling and local environmental knowledge: do they complement or substitute each other. Int J Educ Dev. 2010;30:305-13.

44. Godoy R, Reyes-García V, Broesch J, Firzpatrick I, Giovanninni P, MartinezRodriguez M. Secular changes of indigenous knowledge of useful plants: separating age and cohort effects. J Anthropol Res. 2009;65:51-67.

45. Quinlan MB, Quinlan RJ. Modernization and medicinal plant knowledge in a Caribbean horticultural village. J Anthropol. 2007;21:92-169.

46. Bonet MÀ, Vallès J. Pharmaceutical ethnobotany in the Montseny biosphere reserve (Catalonia, Iberian Peninsula). General results and new or rarely reported medicinal plants. J Pharm Pharmacol. 2003;55:259-70.

47. Uncini Manganelli RE, Camangi F, Tomei PE. Curing animals with plants, traditional usage in Tuscany, Italy. J Ethnopharmacol. 2001;78:171-91.

48. Aziz MA, Adnan M, Khan AH, Sufyan M, Khan SN. Cross-cultural analysis of medicinal plants commonly used in ethnoveterinary practices at South Waziristan Agency and Bajaur Agency, Federally Administrated Tribal Areas (FATA), Pakistan. J Ethnopharmacol. 2018;210:443-68.

49. Cowan MM. Plant products as antimicrobial agents. Clin Microbiol Rev. 1999;12:564-82

50. Carla C, Hank F, lain N, Tomoko M, Donna G, Sonya V. Tobacco smoke is a source of toxic reaction glycation products, Proceedings of the National Academy of Sciences of the United States of America, Manhasset. 1997; NY 11030:1-32.

51. Fukai T, Satoh K, Nomura T, Sakagami H. Preliminary evaluation of antinephritis and radical scavenging activities of glabridin from Glycyrrhiza glabra. Fitoterapia. 2003;74:624-9.

52. Lans C, Turner N, Khan T, Brauer G, Lourenco G, Georges K. Ethnoveterinary medicines used for horses in Trinidad and in British Columbia, Canada. J Ethnobiol Ethnomed. 2006;2:31.

53. Dilshad SMR, Rehman N, lqbal Z, Muhammad G, lqbal A, Ahmed N. An inventory of the ethno veterinary practices for reproductive disorders in cattle and buffaloes, Sargodha district of Pakistan. J Ethnopharmacol. 2008; 117:393-402.

54. Farnsworth NR, Akerele RO, Bingel AS, Soejarto DD, Guo Z. Medicinal plants in therapy. Bull WHO. 1985;63:965-81.

55. Fabricant DS, Farnsworth NR. The value of plants used in traditional medicine for drug discovery. Environ Health Perspect. 2001;109:69-75.

56. Ritter RA, Monteiro MVB, Monteiro FOB, Rodrigues ST, Soares ML, Silva JC. Ethnoveterinary knowledge and practices at Colares island, Pará state, eastern Amazon, Brazil. J Ethnopharmacol. 2012;144:346-52.

57. Kearns RA. Medical geography: making space for difference. Prog Hum Geogr. 1995;19:251-9.

58. Mathias-Mundy E, McCorkle CM. Ethnoveterinary medicine an annotated bibliography lowa State University Research Foundation, Ames, US.1989.

59. Mathias E. Ethno veterinary medicine: harnessing its potential. Vet Bull. 2004; 74:27-37.

60. Monteiro MVB, Bevilaqua CML, Palha MDC, Braga RR, Schwanke K, Rodrigues ST, Lameira OA. Ethnoveterinary knowledge of the inhabitants of Marajo Island, Eastern Amazonia, Brazil. Acta Amazon. 2011;41:233-42.

61. Jabbar A, Raza MA, Iqbal Z, Khan N. An inventory of the ethnobotanicals used as anthelmintics in the southern Punjab (Pakistan). J Ethnopharmacol. 2006;108:152-4

62. Teklehaymanot T, Giday M. Ethnobotanical study of medicinal plants used by people in Zegie Peninsula. Northwestern Ethiopia. J Ethnobiol Ethnomed. 2007:3:12.

63. Sharma R, Manhas RK, Magotra R. Ethnoveterinary remedies of diseases among milk yielding animals in Kathua, Jammu and Kashmir, India. J Ethnopharmacol. 2012;141:265-72.

64. Sharma R, Manhas RK. Ethnoveterinary plants for the treatment of camels in Shiwalik regions of Kathua district of Jammu \& Kashmir, India. J Ethnopharmacol. 2015;169:170-5.

65. Ali-Shtayeh Mohammed S, Jamous RM, Jamous RM. Traditional Arabic Palestinian ethnoveterinary practices in animal health care: a field survey in the West Bank (Palestine). J Ethnopharmacol. 2016;182:35-49.
66. Parthiban R, Vijayakumar S, Prabhu S. Quantitative traditional knowledge of medicinal plants used to treat livestock diseases from Kudavasal taluk of Thiruvarur district, Tamil Nadu, India. Rev Br Farmacogn. 2015;26:109-21.

67. Lulekal E, Asfaw Z, Kelbessa E, Van Damme P. Ethnoveterinary plants of Ankober District, North Shewa Zone, Amhara Region, Ethiopia. J Ethnobiol Ethnomed. 2014;10:21.

68. Heinrich M, Ankil A, Frei B, Weimann C, Sticher O. Medicinal plants in Mexico, healer's consensus and cultural importance. Soc Sci Med. 1998;47:1859-71.

69. Quinlan MB. Ethnomedicine and ethnobotany of fright, a Caribbean culture bound psychiatric syndrome. J Ethnobiol Ethnomed. 2010;6:9.

70. Kavanaugh NL, Ribbeck K. Selected antimicrobial essential oils eradicate pseudomonas spp. and Staphylococcus aureus biofilms. Applied Environ Microbiol. 2012;78:4057-61.

71. Rather MA, Dar BA, Sofi SN, Bhat BA, Qurishi MA. Foeniculum vulgare: a comprehensive review of its traditional use, phytochemistry, pharmacology and safety. Arab J Chem. 2016;9:1574-83.

72. Srinivasan D, Nathan S, Suresh T, Perumalsamy PL. Antimicrobial activity of certain Indian medicinal plants used in folklore medicine. J Ethnopharmacol. 2001;74:217-20

73. Qarar F, Kalhora MA, Badar Y. Antihelmintic properties of some indigenous plants. Hamdard Med. 1998;21:115-7.

74. Ahmad I, Mehmood Z, Mohammad F. Screening of some Indian medicinal plants for their antimicrobial properties. J Ethnopharmacol. 1998;62:183-93.

75. Grewal RC. Medicinal Plants, vol. 53. New Delihi: Campus Books International; 2000.

76. Kamboj VP. Herbal medicine. Curr Sci. 2000;78:35-8.

77. Mahady GB. Are medicinal plants a potential alternative for conventional antibiotics in animal husbandry. Thai J Phytopharm. 2002;9:50-62.

78. Aggarwal KK, Ateeque A, Kumar TS, Neetu J, Gupta VK, Sushil K, Khanuja SP. Antimicrobial activity spectra of Pelargonium graveolens L. and Cymbopogon winterianus Jowitt oil constituents and acyl derivatives. J Med Aromat Plant Sci. 2000;22:544-8.

79. $\mathrm{WHO}, \mathrm{Global}$ action plan on antimicrobial resistance. ISBN978924150976 3. Available at. 〈http://www.who.int/drugresistance/global_action_plan/en/〉. 2015.

80. Singh BR, Verma R, Gupta CP. Antimicrobial drug resistance in bacteria isolated from sick animals and their environment in year 2011-201 2 at Central Disease Diagnostic Laboratory, Indian Veterinary Research Institute, Izatnagar. Noto-are Med (11152889). 2012:1-3.

81. Häsler B, Cornelsen L, Bennani H, Rushton J. A review of the metrics for One Health benefits. Rev Sci Tech. 2014;33:453-64.

82. Butler CD. Infectious disease emergence and global change: thinking systemically in a shrinking world. Infect Dis Poverty. 2012;1:5.

83. Waltner-Toews D. Ecosystem sustainability and health: a practical approach. Cambridge: Cambridge University Press; 2004

84. Steffen W, Hughes L. Climate Commiss. The critical decade 2013: climate change science, risks and response. Common wealth of Australia Department of Industry, Innovation, Climate Change, Science, Research and Tertiary Education. 2013. Available at. Climatecommission.gov.au/report/thecritical-decade-2013/ (accessed on 1 Jan 2018).

85. De La Rocque S, Rioux JA, Slingenbergh J. Climate change effects on animal disease systems and implications for surveillance and control. In Climate change: impact on the epidemiology and control of animal diseases. Rev Sci Tech. 2008;27:339-54.

86. Gallana M, Ryser-Degiorgis M, Wahli T, Segner H. Climate change and infectious diseases of wildlife: altered interactions between pathogens, vectors and hosts. Curr Zool. 2013;59(3):427-37.

87. OHITF, One health. A new professional imperative-One Health Initiative Task Force. American veterinary association, 2008.

88. Graham JP, Leibler JH, Price LB, Otte JM, Pfeiffer DU, Tiensin T, Silbergeld EK. The animal-human interface and infectious disease in industrial food animal production: rethinking biosecurity and biocontainment. Public Health Rep. 2008;123:282-99.

89. National Academy of Sciences, Institute of Medicine Microbial Threats to Health, Emergence Detection, and Response, 2003.

90. Sher H, Barkworth ME, de Boer HJ. Medicinal and aromatic plant cultivation in the Swat valley, north-western Pakistan, for economic development and biodiversity conservation. Genet Res Crop Evol. 2017;64:237-45.

91. Aziz MA, Adnan M, Khan AH, Rehman AU, Jan R, Khan J. Ethnomedicinal survey of important plants practiced by indigenous community at Ladha subdivision, South Waziristan agency, Pakistan. J Ethnobiol Ethnomed. 2016;12:53. 
92. Hussain F, Islam M, Zaman A. Ethnobotanical profile of plants of Shawar Valley, District Swat, Pakistan. Int J Biol Biotechnol. 2006;3:301-7.

93. Ahmad M, Sultana S, Fazl-i-Hadi S, Hadda TB, Rashid S, Zafar M, Khan MA, Khan MPZ, Yaseen G. An ethnobotanical study of medicinal plants in high mountainous region of Chail valley (District Swat-Pakistan). J Ethnobiol Ethnomed. 2014;10:36.

94. Dweba TP, Mearns MA. Conserving indigenous knowledge as the key to the current and future use of traditional vegetables. Int J Inform Manag. 2011; 31:564-71.

Submit your next manuscript to BioMed Central and we will help you at every step:

- We accept pre-submission inquiries

- Our selector tool helps you to find the most relevant journal

- We provide round the clock customer support

- Convenient online submission

- Thorough peer review

- Inclusion in PubMed and all major indexing services

- Maximum visibility for your research

Submit your manuscript at www.biomedcentral.com/submit
Biomed Central 